Mateusz Bourkane

\title{
Nieznane drobiny epistolarne Stanisława Wyspiańskiego
}

Dwa krótkie listy autora Wesela, stanowiące przedmiot niniejszej publikacji, nie zaistniały dotąd w obiegu naukowym i czytelniczym. Zachowane jedynie w rękopisach, nie weszly nawet do fundamentalnej edycji korespondencji artysty, która ukazała się w drugiej połowie $\mathrm{xx}$ wieku nakładem Wydawnictwa Literackiego [Wyspiański 1979-1998]. Oba manuskrypty przechowywane są w Muzeum im. ks. Józefa Jarzębowskiego w Licheniu Starym (sygn. MLr 120), dokąd zostały przewiezione po roku 2006 ze zlikwidowanego Domu Zakonnego Zgromadzenia Księży Marianów w Fawley Court pod Londynem. W Wielkiej Brytanii znajdowały się od czasów II wojny światowej, ocalone z klasztoru na warszawskich Bielanach. Dzieje i zawartość bezcennej kolekcji, w skład której wchodzą prezentowane tutaj autografy Wyspiańskiego, to zresztą zagadnienie osobne, daleko wykraczające poza ramy problemowe skromnego wstępu edytorskiego.

List pierwszy, do Marii Siedleckiej, na cienkim, lekko żółknącym papierze, wymiary arkusza: $21 \times 17 \mathrm{~cm}$. Kartka jednostronnie zapisana niebieskim atramentem, na brzegach zauważyć można ślady po oddarciu lub niezbyt starannym odcięciu. Koperta ozdob- 
nie wytłaczana, z widocznymi pozostałościami laku, zaadresowana została ręką Wyspiańskiego: „Wielmożna Pani Maria Siedlecka odebrać raczy”. Wiadomość druga, do Elizy Pareńskiej, na kolorowej widokówce o wymiarach 13,9 × $9 \mathrm{~cm}$. Ślady na odwrocie sugerują, iż pocztówka przez jakiś czas naklejona była na inny papier lub karton, najprawdopodobniej w czyimś albumie. Wykaligrafowany przez poetę adres: „J. Wielmożna Pani Eliza Pareńska odebrać raczy. Tenczynek (willa Eliza) pod Krzeszowicami. Galizien”. W poniższym zapisie zmodernizowano ortografię, zachowując wszakże w pierwszym liście formę „3ej”, która wydaje się szczególnie charakterystyczna dla piśmiennictwa epoki.

Do wydania rękopisów mogło dojść dzięki informacjom, pochodzącym od Pani Wiesławy Albrecht-Szymanowskiej, wybitnej bibliografi autorki poświęconego Wyspiańskiemu tomu Nowego Korbuta. Serdeczne podziękowania za życzliwość oraz udzieloną pomoc przyjąć zechce także Pani Irena Wawrzyniak z Muzeum im. ks. Józefa Jarzębowskiego w Licheniu Starym. 


\section{Do Marii Siedleckiej}

[Kraków, listopad-grudzień 1901] ${ }^{1}$

Wielce Szanowna Pani².

Jeśli pora ta jest dla W. Szan. Pani dogodną, to będę prosił o łaskawe przybycie jutro około godziny zej po południu³. $\mathrm{Z}$ wysokim poważaniem.

\section{Załączając ukłony i pozdrowienia}

St. Wyspiański

1 List nie jest co prawda datowany, lecz na podstawie wskazówek można ustalić przybliżony czas jego powstania. Jedyny kontakt Wyspiańskiego z Marią Siedlecką, potwierdzony w relacjach źródłowych, miał miejsce właśnie na przełomie listopada i grudnia 1901 roku [więcej informacji na ten temat zob. Kalendarz... 1995: 163]. Nie ulega raczej wątpliwości, że wiadomość wysłana została z Krakowa, w którym mieszkała również Siedlecka. O tym, iż list dostarczył służący lub miejski goniec, świadczy forma adresu oraz brak znaczków i stempli pocztowych.

2 Maria Siedlecka była znaną w Krakowie organizatorką życia społecznego, udzielającą się szczególnie na polu oświatowym. Współtworzyła Towarzystwo Szkoły Ludowej, a także Stowarzyszenie Czytelni dla Kobiet oraz Towarzystwo Opieki nad Ubogą Młodzieżą Szkolną [szerzej o jej życiu zob. Polski słownik... 1996: 530-531].

Planowane spotkanie najprawdopodobniej miało się wiązać z propozycją złożoną Wyspiańskiemu przez Siedlecką w listopadzie 1901 roku: „To, co Wyspiańskiego zirytowało, należy policzyć między innymi i na rachunek p. Marii Siedleckiej $\mathrm{z} \ll$ Czytelni Kobiet Polskich», która przysłała list Wyspiańskiemu, że grono kobiet polskich - czy jak się tam nazywają - uchwaliło wybić medal na cześć «dzieci wrzesińskich» (proces o bicie dzieci we Wrześni przez nauczycieli w szkole, że nie chciały po niemiecku uczyć się religii - wyrok barbarzyński na ich matki - list Sienkiewicza itd.) i prosi, żeby Wyspiański na drugi dzień dał projekt do tego medalu! - List p. Siedleckiej poszedł do pieca - ale to wyprowadziło go z względnego spokoju i chciał dojść, dlaczego ludzie mogą takie pomysły snuć” [Chmiel 1971: 122-123]. Ciekawość, wspomniana tutaj przez Chmiela, musiała skłonić artystę do wyznaczenia spotkania, choć ostatecznie medalu nigdy nie zaprojektował [zob. też Kalendarz ... 1995: s. 163]. 
354

MATEUSZ BOURKANE

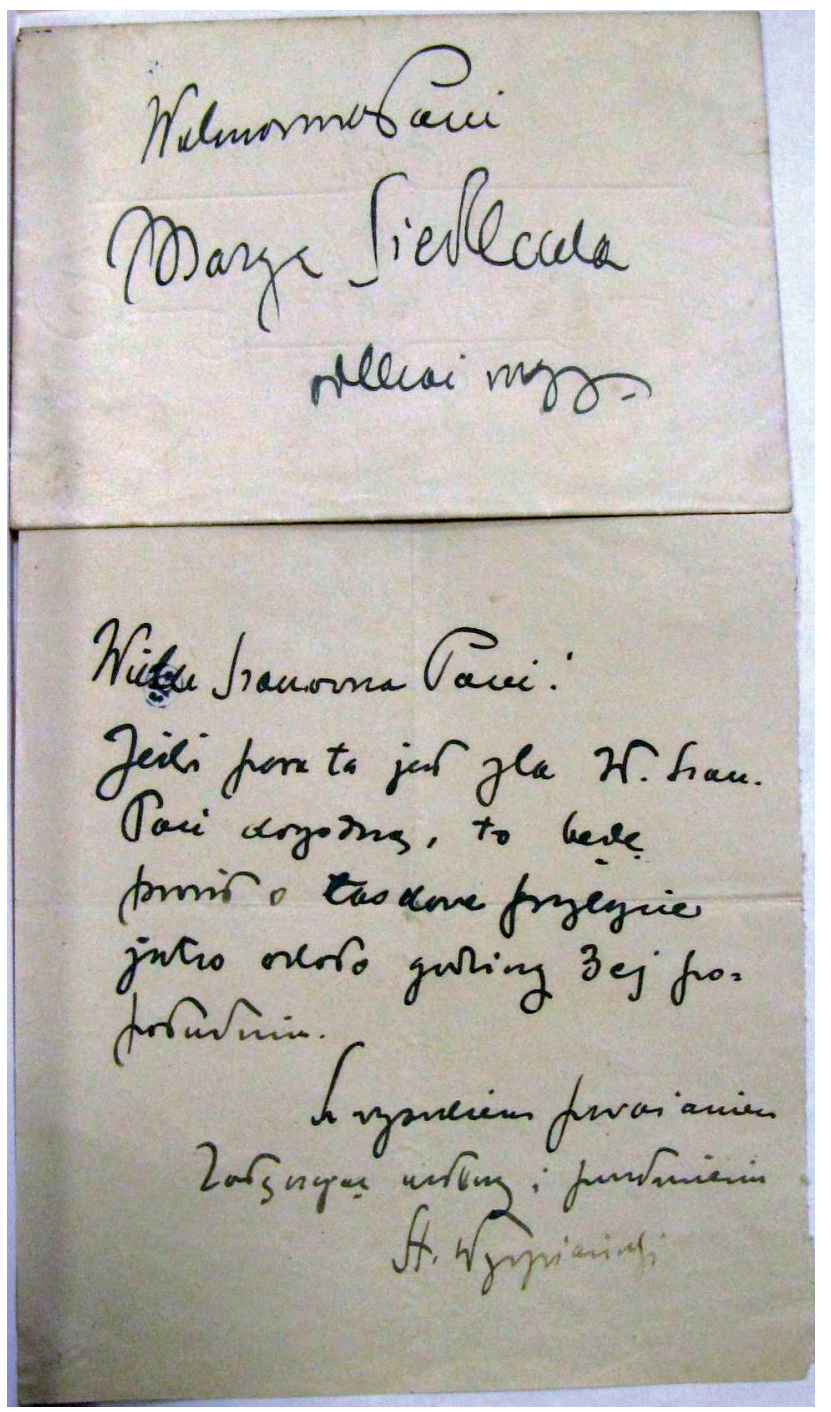

Ryc. 1 List Wyspiańskiego do Marii Siedleckiej.

Ze zbiorów Muzeum im. ks. Józefa Jarzębowskiego w Licheniu Starym 


\section{Do Elizy Pareńskiej}

[Bad Hall]', 23 lipiec 1904

Wielce Szanowna i Łaskawa Pani.

Serdeczne przesyłam pozdrowienia. Gdzie adresować do Pana

Bolesława R.? ${ }^{2}$ Czy imago Pani Zofii jeszcze istnieje? 3

St. Wyspiański

Adres: Bad Hall, poste restante

1 W austriackim uzdrowisku Bad Hall Wyspiański gościł od 19 lipca do 30 sierpnia 1904 roku [zob. Kalendarz ... 1995: 275-297].

2 Chodzi o kompozytora Bolesława Raczyńskiego, szwagra Marii, najstarszej córki Elizy Pareńskiej. Jego przyjaźń i współpraca artystyczna z Wyspiańskim zaowocowała między innymi powstaniem muzyki do Nocy listopadowej [zob. Kalendarz ... 1995: 280]. Warto nadmienić, iż kolejny list do Pareńskiej, wysłany 2 sierpnia 1904 roku, zawiera wzmiankę, nawiązującą do treści prezentowanej tutaj pierwszy raz pocztówki: „Wielce Szanowna i Droga Pani. Dziękuję ślicznie za Jej list, przepraszam, że wtedy pisałem kartkę, ale chciałem mieć jakąś wiadomość o panu Bolesławie niegodziwym, ale niestety mimo obszernego określenia w liście gdzie się będzie znajdował, niepodobna mi było do niego pisać, gdyż nie wiem czy go list trafi. Zresztą rad bym raczej od niego mieć jakie wiadomości. I nie omieszkam się zemścić, jeżeli nie otrzymam w końcu żadnych" [Wyspiański 1979-1998, t. 4: 166].

3 „Imago Pani Zofii”, o które pyta Wyspiański, to prawdopodobnie rodzaj portretowego fresku, przedstawiającego Zofię z Pareńskich Żeleńską. Z zapisków artysty wynika, że dzieło owo wykonał niecałe dwa tygodnie wcześniej, podczas swojej wizyty w Tenczynku: „10 lipca. Powrót z Tenczynka. (Rysowałem panią Zofię Ż. na murze)” [Wyspiański 1998: 371; zob. też Kalendarz ... 1995: 273]. 


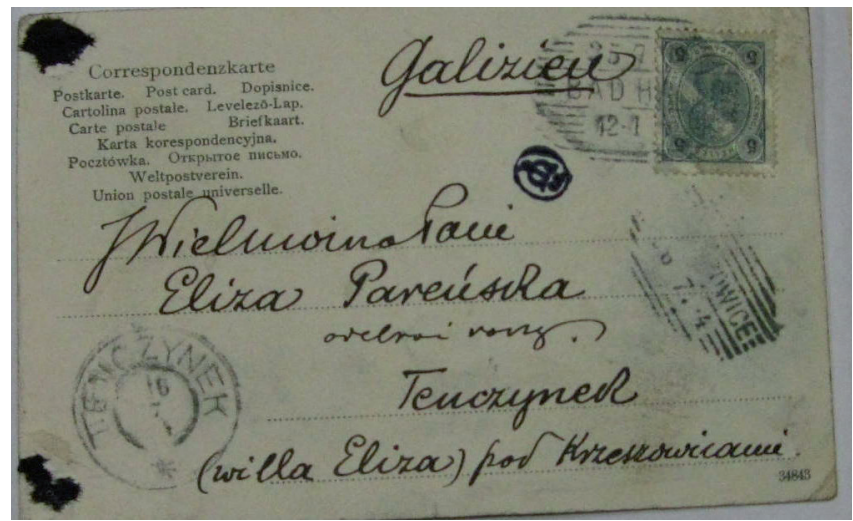

Ryc. 2 List Wyspiańskiego do Elizy Pareńskiej. Ze zbiorów Muzeum im. ks. Józefa Jarzębowskiego w Licheniu Starym

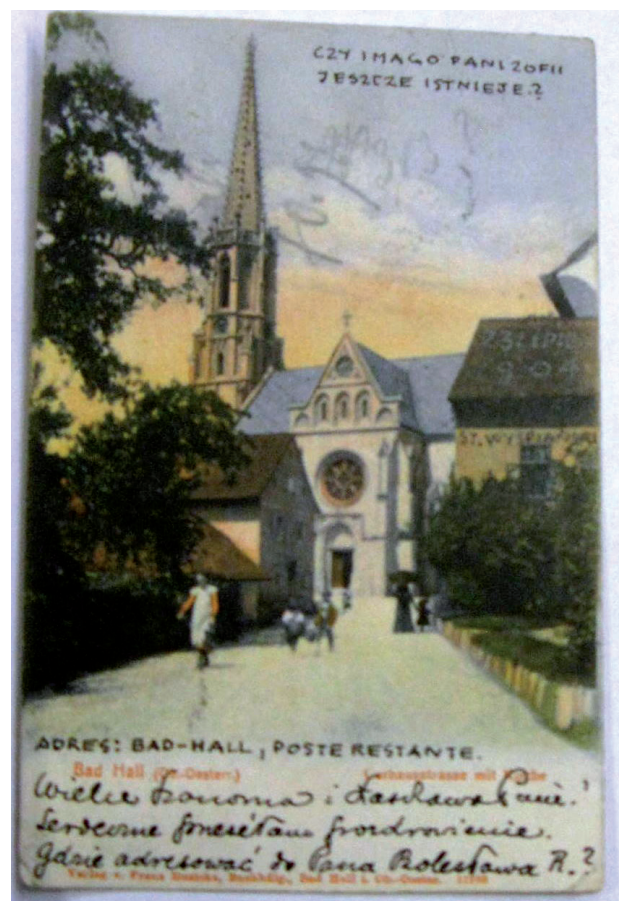

Ryc. 3 List Wyspiańskiego do Elizy Pareńskiej. Ze zbiorów Muzeum im. ks. Józefa Jarzębowskiego w Licheniu Starym 


\section{Bibliografia}

Chmiel Adam (1971), [Zapiski z rozmów z Wyspiańskim], w: Wyspiański w oczach wspótczesnych, zebrał, oprac. i komentarzem opatrzył Leon Płoszewski, t. 2, Wydawnictwo Literackie, Kraków.

Kalendarz życia i twórczości Stanisława Wyspiańskiego (1995), t. 3, oprac. Alina Doboszewska, Wydawnictwo Literackie, Kraków.

Polski słownik biograficzny (1996), t. 36, IH PAN, FNP, Warszawa-Kraków. Wyspiański Stanisław (1979-1998), Listy zebrane, oprac. Leon Płoszewski, Jan Dürr-Durski, Maria Rydlowa, t. 1-4, Wydawnictwo Literackie, Kraków.

Wyspiański Stanisław (1998), Raptularz z 1904 r., w: tegoż, Listy zebrane, oprac. Leon Płoszewski, Jan Dürr-Durski, Maria Rydlowa, t. 4, Wydawnictwo Literackie, Kraków.

\section{Mateusz Bourkane}

\section{Unknown short letters by Stanisław Wyspiański}

The work concerns two short letters by Stanisław Wyspiański, which haven't been published before. The letters, adressed to Maria Siedlecka and Eliza Pareńska, seem to be important in context of the artist's biography.

Keywords: Stanisław Wyspiański; Young Poland; epistolography.

Mateusz Bourkane - adiunkt w Zakładzie Literatury Pozytywizmu i Młodej Polski Instytutu Filologii Polskiej UAM. Publikacje między innymi w „Pamiętniku Literackim”, „Polonistyce”, „W Drodze”, „Poznańskich Studiach Polonistycznych. Serii Literackiej” oraz tomach zbiorowych. Autor zarysu monograficznego O rapsodach Stanisława Wyspiańskiego (2014). Kontakt: gilgalad@amu.edu.pl. 
